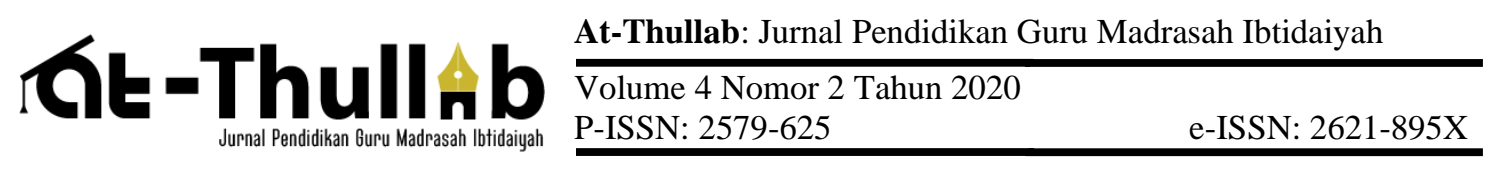

\title{
Media Alternatif Whatsapp (WA) Mengatasi Permasalahan Pembelajaran pada Situasi Pendemi Covid 19 di Kelas PGMI Semester IV
}

\section{Whatsapp (WA) Alternative Media Overcoming Learning Problems in Covid 19 Pending Situations in PGMI Class Semester IV}

\author{
Nazri Adlani ${ }^{*}$, Maria Hanifah ${ }^{2}$ \\ ${ }^{1}$ Program Studi PGMI, Jurusan Tarbiyah, IAIN Takengon, ${ }^{2}$ Program Studi PGMI, \\ STIT Babussalam Aceh Tenggara \\ e-mail: ${ }^{1 *}$ nazriadlani15@gmail.com, ${ }^{2}$ maria.hanifah05@gmail.com
}

\begin{abstract}
This study discusses about whatsapp (WA) alternatives media to overcome learning problems in COVID 19 situation. The research was implemented at IAIN Takengon Semester IVth PGMI Class. This research is motivated by learning that stopped due to the COVID 19 epidemic, understanding of technological advances that are still limited in remote areas of the Indonesian homeland, whatsapp as a medium used by the public, in general, has spread throughout the groundbreaking homeland. The research method used was a descriptive qualitative method with a triangulation of research instruments. The results obtained were divided into three sub-topics. (1) The steps of the learning process using the WA feature are the same as learning in class face to face, namely greetings, delivery of learning objectives, delivery of motivation, opening with an attendance, applying learning methods, and closing by praying and giving assignments or further material. (2) WA features that can be used in learning and its use processes are short messages, videos, pictures, file documents, and voice messages. (3) Evaluation of learning that can be done using WA media, namely Question and Answer, working on the pretest/posttest with the specified time, then sending the results of the work through the personal WA, Presentation, and Discussion; Paper Making; Electronic Book Analysis Making.
\end{abstract}

Keywords: Learning, Media WhatsApp, Covid 19 Pandemic

\section{A. Pendahuluan}

Adanya perkembangan zaman menyebabkan segala aspek bidang kehidupan ikut berkembang termasuk bidang pendidikan. Pendidikan merupakan usaha sadar dan sistematis, yang dilakukan seseorang untuk mempengaruhi peserta didik agar mempunyai sifat dan tabiat sesuai dengan tujuan pendidikan (Achmad, 2000). Tujuan pendidikan tersebut dapat diwujudkan dalam proses pembelajaran baik di dalam maupun di luar kelas. 
Mahasiswa dituntut untuk menentukan informasi secara mandiri dari hasil interaksi mereka dengan lingkungan di dalam maupun luar kampus. Konsep lingkungan meliputi tempat belajar, metode, media, sistem penilaian, serta sarana dan prasarana yang diperlukan untuk mengemas pembelajaran dan mengatur bimbingan belajar, sehingga memudahkan peserta didik belajar (Daryanto, 2010). Teori kontruktivisme menciptakan kemandirian mahasiswa dalam menerapkan ilmu-ilmu yang sudah disampaikan dosen. Teori kontruktivisme juga menciptakan mahasiswa aktif dalam mengikuti pembelajaran (Suparlan, 2019). Peran dari pendidik berdasarkan teori kontruktifisme tersebut hanyalah membimbing.

Berdasarkan tujuan pendidikan dan teori kontruktifisme tersebut memberikan kesempatan kepada pendidik untuk membimbing mahasiswa di luar kelas. Pendemi covid 19 ini menyebabkan teori kontruktivisme tersebut harus dijalankan. Covid 19 adalah suatu wabah penyakit yang disebarkan oleh virus yang dinamakan Corona Virus Disease 2019. Covid 19 merupakan replikasi dan kombinasi dari virus corona yang berkembang di daerah Wuhan Provinsi Hubei Cina yang awalnya terdeteksi pada bulan Desember 2019 (Susilo et al., 2020).

Covid 19 adalah virus yang menyerang pernafasan manusia. Penyebaran virus Corona diketahui melalui dopler yang tertempel di benda hidup atau mati yang secara tidak langsung bisa menular ke manusia lain. Virus Covid 19 jika mendapatkan inang tepat yaitu sistem pernafasan manusia dapat berkembang menjadi penyakit yang menyerang paru-paru manusia. Covid 19 memiliki penyebaran yang mudah dari manusia ke manusia lainnya. Covid 19 ini sudah menyerang 190 negara dan WHO sudah menyatakan sebagai pendemi (Susilo et al., 2020). Permasalah tersebut berdampak pada pendidikan yang biasanya berjalan normal di Indonesia menjadi berhenti.

Hal tersebut dikarenakan Covid 19 sudah mewabah secara global seluruh dunia hingga sampai penjuru nusantara Indonesia, baik kota maupun desa. Dampak covid 19 ini sangat besar bagi dunia terkhususnya Indonesia. Hal ini berdampak pula pada pembelajaran yang berlangsung di Indonesia.

Indonesia tidak lain merupakan negara kepulauan yang memiliki tingkat kemajuan teknologi yang berbeda-beda tiap pulaunya. Berdasarkan permasalahan keberlanjutan pembelajaran akibat pendemi Covid 19 ini, mengharuskan pembelajaran via online yang menciptakan kemandirian. Selain itu pembelajaran daring/online melalui SPADA yang diluncurkan oleh wakil presiden Indonesia pada 15 Oktober 2014 bertujuan untuk menerapkan teknologi pendidikan sebagai alih kredit memecahkan salah satu tantangan pendidikan tinggi sehingga menciptakan pendidikan tinggi yang bermutu (Chaeruman, 2017). 
Berdasarkan hasil pengamatan di lingkungan kampus IAIN Takengon pembelajaran daring atau via online tidak secara langsung dapat berjalan dengan lancar. Termasuk hasil pengamatan di daerah pelosok tanah air salah satunya adalah Aceh Tengah, siswa dan mahasiswa mengalami kesulitan dengan ketersediaan handphone dan laptop untuk pembelajaran daring atau online, hal ini dikarenakan keterbatasannya masyarakat akan pemahaman kemajuan teknologi. Mengatasi permasalahan tersebut secara cepat tanggap darurat yang dialami Negara Indonesia sebagai citivas akademik, memberikan solusi pembelajaran Via Whatsapp (WA).

Pembelajaran via WA ini sudah dilakukan beberapa peneliti salah satunya yaitu penelitian dari Pangestika mengatakan ada pengaruh penggunakan media WA yang digunakan untuk penyebaran informasi pembelajaran (Pangestika, 2018). Jurnal yang ditulis oleh Trisnani juga menyimpulkan penggunaan media WA memberikan akses yang cepat untuk menyampaikan pesan yang dikirim kepada sasaran yang diharapkan (Trisnani, 2017). Berdasarkan penelitian tersebut menyimpulkan media WA dapat digunakan untuk pembelajaran online.

WA juga merupakan media yang keseluruhan masnyarakat sudah menggunakan sebagai media sosial untuk saling berkomunikasi. WA ini memiliki vitur mengirim video, audio untuk rekaman percapakan, maps untuk mengirimkan koordinat peta kamera menggambil gambar atau mengirim gambar, dan pesan teks (Jumiatmoko, 2016). Fitur pesan pada WA yang digunakan sudah mencapai 30 milliar pesan dalam sehari (Rahartri, 2019).

Penggunakan WA digunakan karena dapat terjangkau oleh mahasiswa baik di desa atau dikota dan biaya kuota internet yang digunakan sangat murah dan terjangkau bagi kalangan ekonomi kurang mampu, dibandingkan dengan aplikasi lainnya (Citra, 2018).

Observasi awal juga dilakukan pada kelas PGMI semester IV IAIN Takengon di mana mahasiswa sebagian besar tidak memiliki laptop dan ada dua mahasiswa tidak memiliki HP smartphone. Untuk mengatasi proses pembelajaran yang harus tetap berjalan akibat COVID 19 ini, kemungkinan terbesar yang bisa dilakukan hanyalah menggunakan media yang mudah dan tidak menghabiskan kuota internet terlampau banyak yaitu media WA. Dua mahasiswa lainnya bergabung dengan teman yang dekat dengan rumahnya di saat pembelajaran berjalan.

Kelas PGMI ini dipilih karena kelas yang mana akan terjun sebagai guru MI/SD. Dimana guru MI/ SD sangat berperan dalam pembentukan karakter awal seorang anakanak penerus bangsa Indonesia. Berdasarkan penjabaran di atas dapat ditarik kesimpulan yang menghasilkan judul dari sebuah penelitian yaitu Media Alternatif Whatsapp (WA) Mengatasi Permasalahan Pembelajaran di Situasi Pendemi Covid 19 di Kelas PGMI Semester IV. 
Pernyataan di atas mengandung tujuan masalah penelitian ini yaitu untuk (1) Mengetahui langkah-langkah proses pembelajaran menggunakan fitur WA. (2) Mengetahui Fitur WA apa saja yang bisa digunakan dalam pembelajaran dan proses penggunaaanya. (3) Mengetahui evaluasi pembelajaran yang bisa dilakukan menggunakan media WA.

Mengetahui tujuan dari penelitian ini di atas, hasil penelitian ini diharapkan dapat digunakan untuk mengenalkan kepada mahasiswa dan kampus tentang integrasi teknologi menggunakan media WA ke dalam pembelajaran; Selain itu juga diharapkan dapat meningkatan kualitas pembelajaran; Meningkatan akses pendidikan melalui pemanfaatan media online berupa leptop/ smartphone/ tablet sebagai alternative media pembelajaran mandiri untuk mahasiswa. Penelitian ini dapat digunakan sebagai rujukan bagaimana proses pelaksanaan pembelajaran menggunakan media WA yang lebih terperinci.

\section{B. Metode}

Metode penelitian ini adalah penelitian kualitatif deskriptif. Subjek penelitian yang digunakan adalah kelas PGMI semester IV tahun ajaran 2019/2020 IAIN Takengon. Subjek penelitian dipilih menggunakan teknik pemilihan dengan tujuan tertentu. Tujuan penggunaan subjek kelas PGMI yaitu kelas yang memiliki keterbatasan dalam kepemilikan laptop dan merata tempat tinggal di seluruh daerah Aceh Tengah.

Peneliti mengamati proses belajar mengajar yang dilakukan menggunakan daring WA. Tujuan dari penelitian ialah menggumpulkan informasi tentang pelaksanaan pembelajaran daring menggunakna WA sebagai solusi permasalahan pendemi COVID 19 dan evaluasi-evaluasi yang sudah diterapkan. Tujuan penggunaan metode kualitatif deskriptif adalah agar mendapatkan gambaran secara mendetail tentang pembelajaran yang berlangsung selama satu semester.Waktu penelitian ini adalah semester IV pada tahun ajaran 2019/2020 pada kelas PGMI.

Penelitian kualitatif menghasilkan data penelitian yang lebih berkenaan dengan intepretasi data yang ditemukan di lapangan. Metode penelitian kualitatif juga disebut sebagai metode naturalistik, sebab penelitian dilakukan secara alamiah. Penelitian kualitatif dilakukan secara hati-hati dan intensif, peneliti ikut campur di lapangan dan melakukan secara hati-hati, melakukan analisis reflektif dan mencatat laporan penelitian secara mendetail (Sugiyono, 2014).

Teknik pengumpulan data yang digunakan menggunakan teknik tringulasi data. Instrumen penelitian yang digunakan adalah lembar dokumen, foto, dan lembar observasi. Teknik analisis dalam penelitian ini adalah mengunakan teknik analisis deskriptif kualitatif. Teknik deskriptif kualitatif adalah menjabarkan dan menjelaskan proses yang terjadi selama pembelajaran secara detail (Widoyoko, 2014). 
Penelitian kualitatif ini dilakukan dengan cara dosen merekam setiap proses belajar mengajar mahasiswa dan memberikan hasil evaluasi dari proses belajar mengajar yang telah diterapkan. Dosen memberikan materi dan mengevaluasi hasil setiap pembelajaran dan melihat respon yang dilakukan mahasiswa dalam percakapan WA yang digunakan.

Tahap penelitian dilakukan setiap pertemuan selama 14 pertemuan disaat pembelajaran online wajib diterapkan di masa pandem ini. Dosen selalu merekam perkembangan dan proses pelaksanaan pembelajaran yang berlangsung menggunakan media WA. Dosen juga melakukan pengamatan dan memberikan penilaian dalam setiap evaluasi yang diterapkan menggunakan media WA tersebut.

\section{Hasil dan Pembahasan}

Penelitian ini membahas tentang pembelajaran via whatsapp (WA) alternatif mengatasi permasalahan pembelajaran dalam situasi pendemi Covid 19. Tujuan dari penelitian ini yaitu membahas langkah-langkah proses pembelajaran menggunakan fitur WA; Fitur WA apa saja yang bisa digunakan dalam pembelajaran dan proses penggunaaanya; Evaluasi pembelajaran yang bisa dilakukan menggunakan media WA.

\section{Pembelajaran Daring/ Online}

Pembelajaran menurut Dimyanti dan Mudjiono merupakan suatu yang dipersiapkan oleh dosen guna menarik dan memberi informasi kepada mahasiswa, sehingga dengan persiapan yang dirancang oleh dosen dapat membantu mahasiswa dalam menghadapi tujuan (Dimyanti \& Mudjiono, 2009).

Pembelajaran daring adalah program pembelajaran kelas dimana pembelajaran dilakukan dalam jaringan internet pada kelomopok tertentu yang masif dan luas. Pembelajaran daring dapat dilakukan secara gratis atau berbayar. Pembelajaran dari dapat dilakukan untuk kelompok kelas yang berjumlah banyak (Yudhanto et al., 2015). Pembelajaran daring adalah pembelajaran dalam jaringan. Jaringan yang digunakan adalah jaringan internet (Kemenristekdikti, 2017).

Pembelajaran daring dapat dikatakan sebagai pembelajaran online di mana mahasiswa menggunakan jaringan internet untuk terhubung satu sama lain. Pembelajaran daring tidaklah berbeda dengan pembelajaran tatap muka, pembelajaran daring dirancang juga untuk membantu mahasiswa mencapai tujuan pembelajaran yang dirancang.

\section{Prinsip Desain Pembelajaran Daring}

Menurut Naidu pembelajaran daring yang bermutu memiliki desain yaitu, sebagai berikut. 
a. Identifikasi capaian pembelajaran mahasiswa mencangkup pengetahuan, keterampilan, dan sikap.

b. Menyusun strategi penilaian (assesment) selaras dengan capaian pembelajaran

c. Menyusun aktivitas dan tugas pembelajaran yaitu menyajikan materi pembelajaran aktif, pengetahuan dibangun dalam tingkat dasar menuju keterampilan tingkat tinggi aplikasi, integrasi, dan analisis.

d. Mejamin keseimbangan kehadiran dosen dalam memberi materi, interaksi sosial, dan beban kognitif (Naidu, 2006).

Prinsip pembelajaran daring berdasarkan definisi di atas adalah pembelajaran yang disusun tidak berbeda dengan pembelajaran tatap muka, hanya saja media yang digunakan bertambah media internet sebagai sara komunikasi dan keterhubungan satu sama lain.

\section{Tujuan pembelajaran Daring}

Pembelajaran daring bertujuan untuk memberikan pembelajaran yang memiliki mutu secara online/dalam jaringan. Sifat dari pembelajaran adalah masif dan terbuka menjangkau banyak audiens (Yudhanto et al., 2015). Tujuan dari pembelajaran daring adalah memiliki mutu sebagai suatu pembelajaran dan menjangkau banyak audiens. Tujuan belajar tidak hanya berorientasi pada penguasaan materi, namun juga memberikan pengalaman jangka panjangberupa keterampilan dan internalisasi tata nilai (Priatmoko \& Dzakiyyah, 2020).

\section{Fungsi dari Pembelajaran Daring}

Penghubung antara dosen dan mahasiswa menggunakan jaringan internet (Sofyana \& Rozaq, 2019). Fungsi dari pembelajaran daring tersebut memberi arti pembelajaran yang dapat dilakukan dimanapun dan kapanpun dengan syarat adanya jaringan internet.

\section{Mata Kuliah Daring}

Mata kuliah utuh yang dapat diakses dan digunakan oleh siapa saja secara online yang disesuaikan dengan standar proses dans standar isi (Yudhanto et al., 2015). Mata kuliah daring juga harus mewajibkan disesuaikan dengan standar isi dan standar proses pembelajaran yang disusun dalam rancangan pembelajaran.

\section{WhatsApp}

Whatsapp adalah salah satu media yang banyak penggunanya untuk kepentingan sosial, dan sebagai alat untuk menyampaikan pesan baik secara pribadi atau kelompok (Trisnani, 2017).

Media Whatsapp adalah suatu media yang sering disingkat menjadi WA. WA adalah media sosial yang dapat diunduh di handphone smartphone. Media ini dapat aktif saat pengguna memiliki data internet (Suryadi, E., M.H.Ginanjar., 2018). 
WA adalah aplikasi pesan lintas platfosrm, di mana penggunanya tidak dikenakan tarif saat menggunakannya. Hanya saja menggunakan kuota internet. Hal ini dikarenakan WA adalah aplikasi yang sama dengan email, facebook, dan lain-lainnya. Penggunaan WA dapat digunakan untuk obrolan online, mengirim berbagai file, bertukar foto, video, video call, telphone pribadi atau telphone grup, dan lainnya.

Hasil penelitian dan pembahasan ini terbagi menjadi beberapa sub pokok pembahasan, yaitu sebagai berikut.

\section{Langkah-langkah proses pembelajaran menggunakan fitur WA.}

Pembelajaran menggunakan fitur WA dapat menggunakan beberapa metode pembelajaran:

\section{a. Metode Diskusi Tanya Jawab}

1) Setiap mahasiswa memiliki smartphone dan aplikasi WA.

2) Membuat grup WA belajar dan memasukan semua mahasiswa kedalam grup.

3) Dosen membuka proses pembelajaran dengan salam dan memberikan presensi kosong berupa chart list untuk menulis nama kepada mahasiswa, sehingga mengetahui siapa saja yang mengikuti proses pembelajaran.

4) Proses absensi mahasiswa dengan mengisi daftar hadir satu persatu mengetik nama dan menggunakan nomor WA masing-masing.

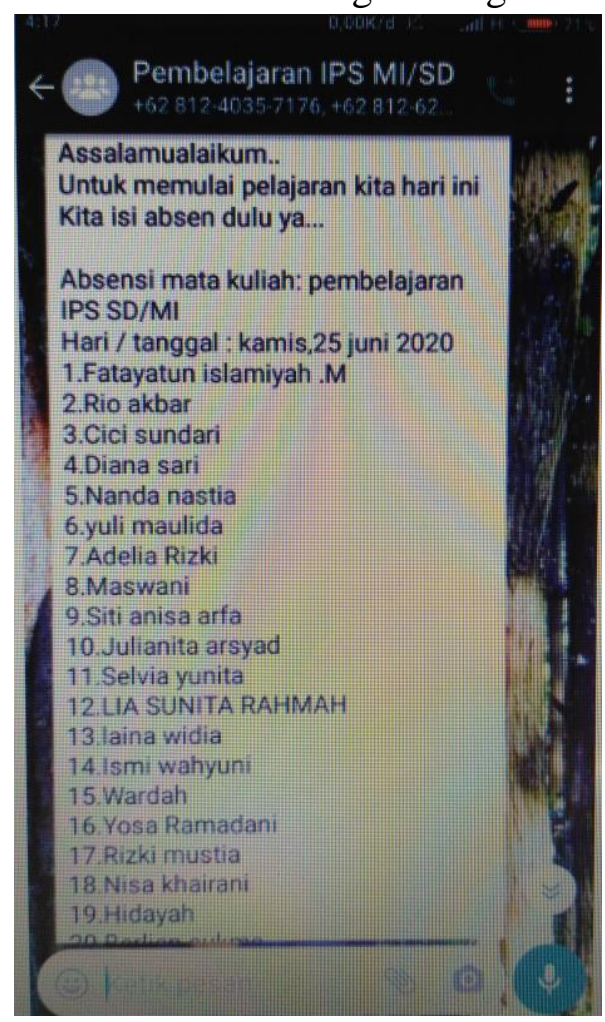

Gambar 1. Presensi Mahasiswa 
5) Selagi mahasiswa mengisi presensi, dosen akan memberikan materi yang akan di bahas pada pertemuan online di grup WA.

6) Materi yang diberikan dapat berupa video, PPT, Modul, dan word.

Berikut beberapa contoh gambar materi yang digunakan

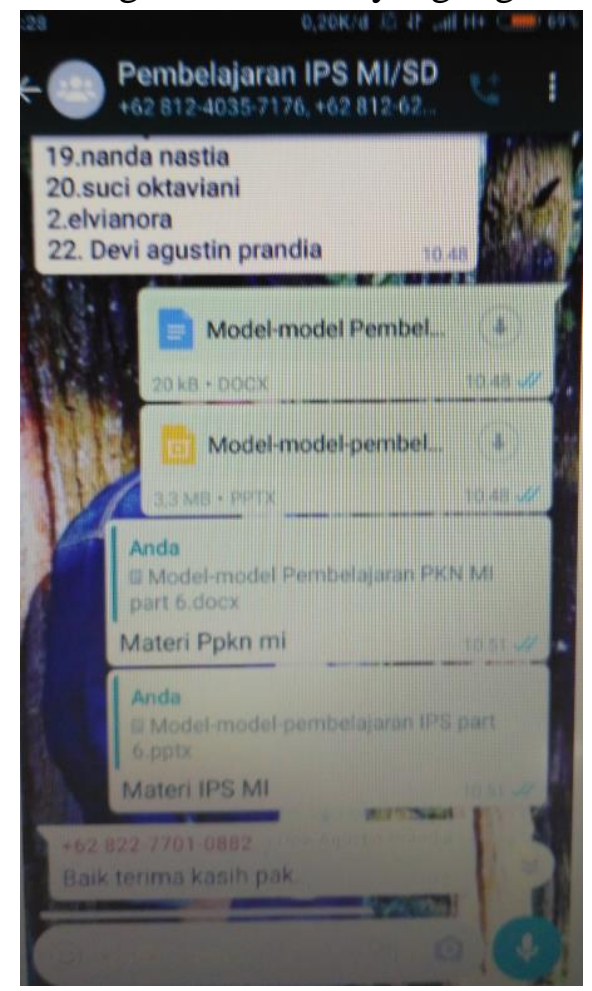

Gambar 2. Materi Pembelajaran

7) Kemudian setiap mahasiswa akan mengunduh materi yang diberikan dosen di dalam grup.

8) Mahasiswa akan membaca materi tersebut dan dosen memberikan kesempatan untuk bertanya kepada mahasiswa.

9) Keaktifan mahasiswa dapat dilihat dari mahasiswa yang banyak memberikan pertanyaan dan sanggahan atau mengomentari pertanyaan dari mahasiswa yang lain.

10) Setelah mahasiswa tidak ada yang bertanya lagi ataupun menjawab, dosen akan menanyakan kepada mahasiswa secara rendom untuk mengetahui tingkat pemahaman dan keseriusan mahasiswa dalam membaca materi yang diberikan.

11) Dosen kemudian menutup perkuliahan dengan salam dan doa serta meyampaikan materi dipertemuan selanjutnya/ memberikan tugas makalah.

Metode diskusi tanya jawab adalah model paling sederhana yang bisa digunakan dalam pembelajaran daring menggunakan media WA ini. Metode ini lebih efektif apabila mahasiswa berperan aktif selama pembelajaran. Dengan memberikan kesempatan kepada mahasiswa bertanya disitu pula dosen akan 
memberikan nilai plus (+) pada mahasiswa yang aktif bertanya. Jumlah mahasiswa yang aktif bertanya pada kelas PGMI semester IV di tahun ajaran 2019/2020 adalah sebanyak 5 orang.

Tujuan dari diskusi ini menurut (Ermi, 2015) adalah mahasiswa terdorong berpartisipasi secara optimal tanpa aturan yang keras namun sesuai dengan etika yang ditetapkan oleh moderator. Diskusi ini membentuk percakapan antar mahasiswa kepada mahasiswa lain yang dihadapkan suatu permasalahan sehingga dapat bertukar pikiran untuk memecahkan masalah secara bersama-sama.

b. Metode Presentasi Mahasiswa

1) Pertemuan pertama dosen membagikan kelompok mahasiswa dengan proses undian menggunakan media WA pesan singkat.

2) Dosen memberikan tugas dan tema dari makalah yang harus disusun mahasiswa melalui dokumen file yang ada di fitur WA.

3) Pertemuan kedua mahasiswa mengirimkan video presentasi dan makalah yang disusun melalui media WA.

4) Mahasiswa lain meyimak video presentasi mahasiswa lain yang diberi tugas dengan menguduh video yang dikirim dalam kelompok belajar menggunakan WA.

5) Mahasiswa memberikan pertanyaan kepada kelompok lain dengan menyebutkan nama dan pertanyaan melalui chat pesan menggunakan media WA.

6) Kelompok tersebut diberi tugas menjawab pertanyaan mahasiswa tersebut.

7) Hasil presentasi disimpulkan oleh kelompok yang bertugas dapat menggunakan fitur pesan singkat atau pesan suara menggunakan media WA.

Metode presentasi mahasiswa dituntut mahasiswa menyajikan video presentasinya yang dikirim menggunakan media WA. Di dalam metode presentasi mahasiswa ada yang bertugas sebagai moderator dan presenter serta sebagai penanya. Keaktifan mahasiswa dalam metode presentasi akan terlihat dengan jelas dengan banyak pertanyaan dari kelompok lain kepada teman lain yang sedang mempresentasikan hasil makalah yang dibuat.

Presentasi merupakan sebuah komunikasi. Komponen dari presentasi adalah pem beri pesan (komunikator), media yang digunakan, penerima esan (audiens). Presentasi yang baik apabila audiens memahami pesan yang disampaikan oleh komunikator (LIPI, 2015). 


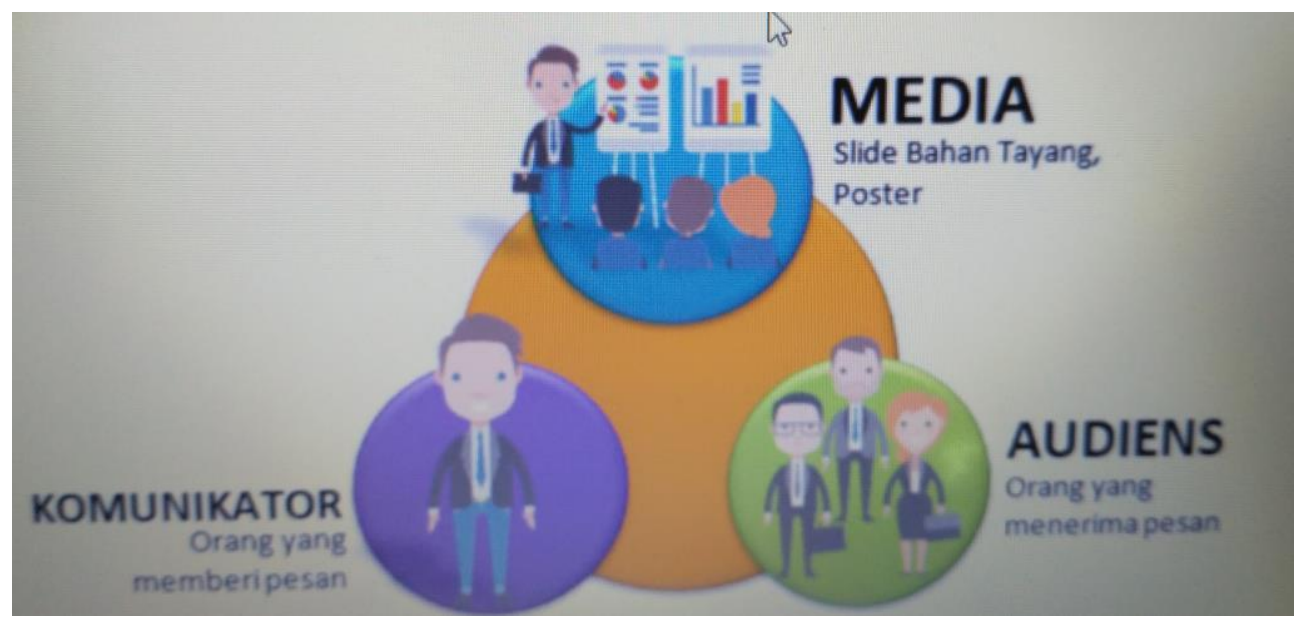

Gambar 3. Pusdiklat Peneliti LIPI 3 komponen yang mendukung Presentasi

\section{Proses Penggunaan Fitur WA dalam pembelajaran}

Pengaruh media sosial pada eramilenial ini sangatlah berdampak sekali pada kalangan anak-anak, remaja, dewasa, hingga tua. Pada era-Covid 19 sekarang ini mahasiswa menggunakan aplikasi WA sebagai media dalam proses forum diskusi dan penyebaran materi pembelajaran dengan cepat. WA menjadi situs yang banyak digunakan oleh seluruh kalangan, dikarena sedikitnya kuota yang dibutuhkan untuk mengoperasikannya. Selain itu pengoperasiannya juga tidak sulit untuk banyak kalangan. Masyarakat hanya membutuhkan nomor teleponnya dan mengaktifkan akun WA-nya kemudian secara otomatis nomor telepon yang tersipan dapat diketahui terdaftar sebagai pengguna WA atau tidak.

WA saat ini sebagai aplikasi pengganti telepon manual yang bisa dilakukan pada HP non android. Fitur-fitur WA yang digunakan dalam pembelajaran di PGMI semester IV ini adalah sebagai berikut.

a. Chat messenger

Chat messanger atau disebut pesan singkat digunakan mahasiswa untuk melakukan aktivitas pembelajran online menggunakan WA baik berupa memberikan pertanyaan, menjawab pertanyan, absensi manual, atau membuka forum diskusi setelah presentasi. Berikut contoh penggunakan pesan singkat WA yang digunakan dalam penelitian ini. 

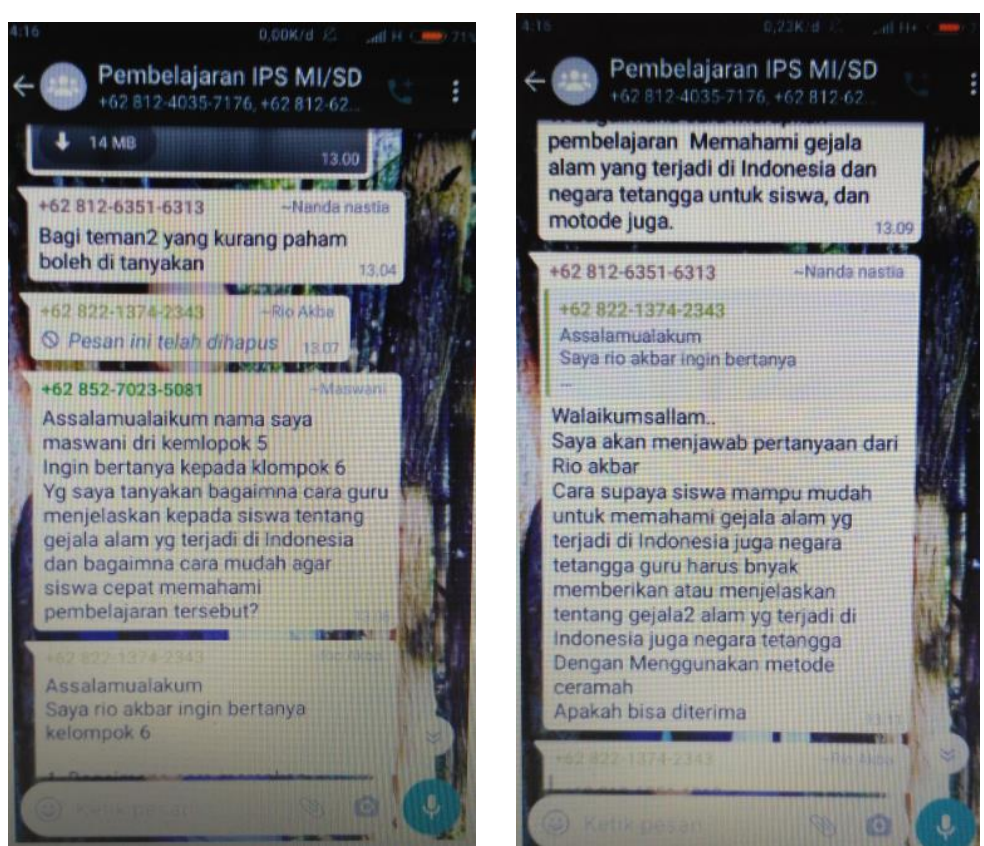

Gambar 4. Contoh Chat yang Dilakukan Mahasiswa dan Dosen

b. Video

Video pada fitur WA digunakan untuk mengirimkan hasil presentasi tugas mahasiswa dan video pembelajaran yang telah disiapkan oleh Dosen. Berikut adalah contoh screenshoot video yang telah dilakukan.

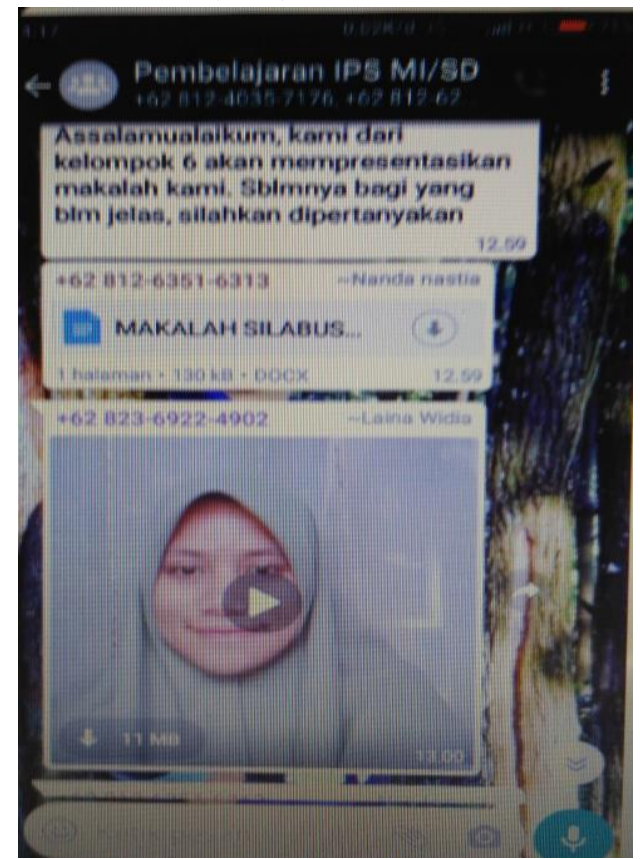

Gambar 5. Video Presentasi Mahasiswa 
c. Image
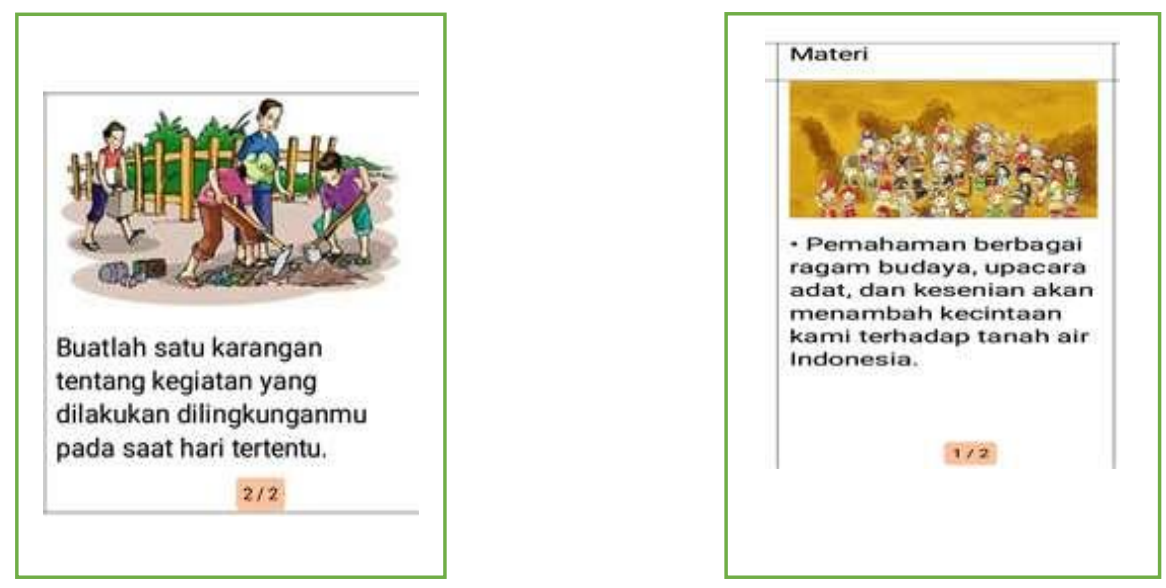

Gambar 6. Contoh Gambar Tugas

Gambar di atas adalah contoh gambar tugas berupa image yang dikirim pada mahasiswa.

Immage atau gambar digunakan mahasiswa sebagai tugas yang diberikan dosen dalam menganalisis buku tematik SD/MI. berikut adalah contoh gambar yang digunakan dalam pembelajaran online melalui WA.

d. Voice Mail (Pesan Suara)

Pesan suara digunakan salah satunya mengirim perintah suara penugasan yang diberikan dosen kepada mahasiswa agar lebih jelas pemahaman tugas yang diberikan.

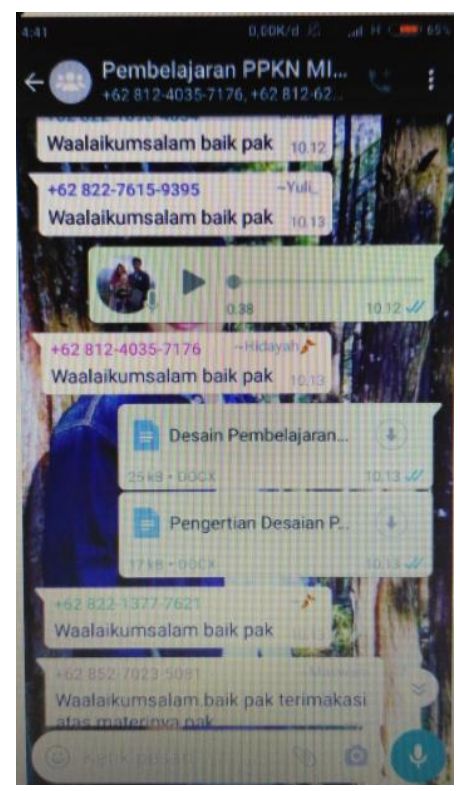

Gambar 7. Pesan suara 
e. File Messanger (Pengiriman Dokumen)

Pengiriman dokumen file menggunakan media WA sangatlah banyak digunakan dalam pembelajaran online. Pengiriman dokumen melalui fitur WA tersebut yaitu untuk pengiriman tugas oleh dosen, materi kuliah, dan pengiriman tugas dari mahasiswa.
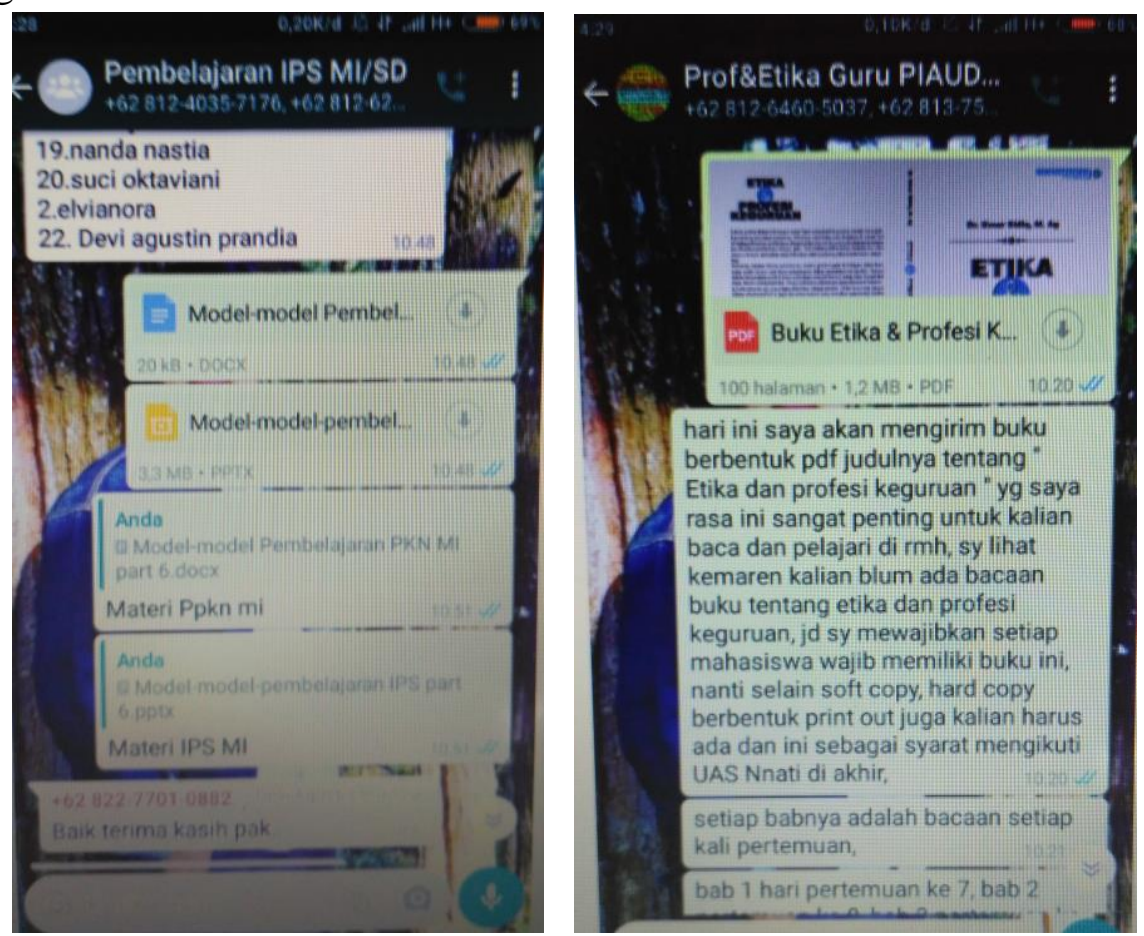

Gambar 8. Dokumen yang dikirim

\section{Evaluasi pembelajaran menggunakan media WA.}

Evaluasi pembelajaran daring dilakukan melalui empat subproses yaitu:

a. Perencanaan: rencana evaluasi mencangkup tujuan, pendekatan, waktu, evaluator, parameter, kriteria, metode, dan intrumen yang digunakan.

b. Realisasi: pelaksanaan evaluasi

c. Analisis: memperhatikan biaya, hasil, dan manfaat evaluasi.

d. Optimasi/ Perbaikan: untuk meningkatkan efisiensi dan efektifitasnya (Yudhanto et al., 2015).

Perencanaan dari evaluasi pembelajaran harus dirumuskan secara detail yaitu jelas dan spesifik, selain itu juga secara terurai dan komprehensif. Dengan perencaan tersebut diharapkan dapat bermakna dalam menentukan langkah-langkah selanjutnya (Arifin, 2013). Evaluasi maka dari itu adalah suatu rencana penilaian yang akan dilakukan oleh pendidik pada penelitian ini adalah dosen.

Evaluasi merupakan suatu proses pengumpulan, analisis, dan penyajian informasi yang dapat digunakan sebagai bahan untuk pengambil keputusan dan program 
selanjutnya (Widoyoko, 2014). Evaluasi adalah seluruh komponrn dari input, proses, hingga hasil belajar (Widoyoko, 2014).

Evaluasi pembelajaran adalah berbeda dengan hasil belajar. Evaluasi pembelajaran disusun dengan rancangan, kemudian pelaksanaannya, kemudian analisisnya, dan yang terakhir adanya perbaikan dari hasil evaluasi.

Evaluasi pembelajaran yang bisa dilakukan menggunakan media WA yaitu

a. Tanya jawab

Tanya jawab dilakukan dosen kepada mahasiswa atau mahasiswa kepada mahasiswa lain baik saat presentasi dilakukan atau pembelajaran berlangsung. Evaluasi menggunakan metode tanya jawab merangsang mahasiswa melatih dan mengembangkan daya pikir dan daya ingat, mengembangkan keberanian bertanya dan menjawab, menjadi daya ingat tersendiri pada mahasiswa, sehingga menjadikan mahasiswa memiliki rasa ingin tau dan melakukan penyelidikan (Basrudin, Ratman, \& Gagaramusu, 2014).

Proses evaluasi berupa tanya jawab menggunakan WA dilakukan dengan cara dosen memberikan kesempatan bertanya kepada mahasisiwa dengan mengirim rekaman suara atau pesan singkat, kemudian mahasiswa mebalas dengan pertanyaan yang dikirim melalui pesan singkat/ pesan suara. Selanjutnya, dosen akan memberikan kesempatan kepada mahasiswa yang mampu untuk menjawab pertanyaan tersebut. Jika tidak ada, dosen yang akan memberikan penjelasan.

b. Mengerjakan pretest/ postest dengan waktu yang ditentukan kemudian mengirimkan hasil pengerjaan soal melalui WA pribadi.

Pretest dan postest dapat berjalan lancar dengan memberikan motivasi kepada mahasiswa untuk mengerjakan secara individu dan hasil pekerjaan tidak diperbolehkan sama persis seperti mahasiswa lainnya. Soal yang diberikan berupa soal analisis sesuai pemahaman masing-masing mahasiswa. Penerapan kegiatan pretest dan post-test melalui WA dilakukan dengan cara dosen mengirimkan soal menggunak dokumen file berupa word. Selanjutnya, mahasiswa mendownload soal tersebut dan kemudian menjawabnya dengan waktu yang ditentukan. Setelah pengerjaan selesai, mahasisiwa mengirimkan tugas jawabannya dengan pesan pribadi bisa berbentuk dokumen file word atau berupa foto.

Pemberian pre-test dan post-test dapat meningkatkan hasil belajar menurut penelitian dari (Effendy, 2016). Hasil Pre-test dapat mengintegrasikan pengetahuan yang dimiliki mahasiswa dengan pengetahuan baru. Hasil post-test untuk mengukur kemamuan mahasiswa dalam menguasai bahan ajar yang telah diberikan (Effendy, 2016). 


\section{c. Presentasi dan Diskusi}

Presentasi menggunakan media WA dilakukan dengan sebelumnya mahasiswa kerja kelompok/diskusi di rumah masing-masing dengan metode masing-masing yang digunakan. Mahasiswa menyusun makalah yang menjadi tugas mereka secara berkelompok. Setiap kelompok memvideokan kegiatan kelompoknya, kemudian mahasiswa tersebut mempresentasikan dengan cara menjelaskan makalah yang disusun dalam video. Maka dari itu, terbentuk kreatifitas dan keaktifan mahasiswa dalam mengikuti pembelajaran.

d. Pembuatan Makalah

Makalah disusun secara berkelompok yang kemudian mahasiswa membuat video presentasi penjelasan makalah yang disusun dan kegiatan penyususnan makalah yang dilakukan, setelah itu mahasiswa lain menonton video yang disusun dan mengomentari hasil presentasi mahasiswa lainnya. Media WA digunakan untuk mengirimkan video yang dibuat mahasiswa kedalam grupp kelompok pembelajaran.

e. Pembuatan Analisis Buku Elektronik

Pembuatan analisis buku tematik elektronik sebagai hasil dari penilaian UTS (ujian tengah semester) yang dilakukan mahasiswa secara individu. Tema yang diberikan dibagi merata kepada setiap mahasiswa. Media WA digunakan sebagai sarana mengirim hasil pembuatan tugas analisis buku elektronik yang dilakukan mahasiswa dengan mengirim dokumen file.

Berdasarkan hasil dan pembahasan di atas, penggunaan media sosial berupa Whatshap (WA) dapat digunakan sebagai alternatif media pembelajaran dimasa pandemi COVID-19 saat ini. Penggunaan WA sebagai media pembelajaran dapat digunakan sebagai alat komunikasi antar mahasiswa dan dosen dalam kondisi jarak jauh. Penelitian ini juga menemukan dimana media WA mampu memberikan kenyamaan bagi mahasiswa saat mengikuti perkuliahan online. Dari segi biaya yang dikeluarkan juga terjangkau oleh mahasiswa. Selain itu, fitur-fitur yang diberikan WA juga cukup untuk memenuhi kegiatan yang disusun dalam rancangan pembelajaran. Rancangan pembelajaran yang bisa diterapkan yaitu mengirim video penjelasan pembelajaran dengan kualitas yang tidak buruk dan ukuran tidak besar. WA juga dapat digunakan untuk menerapkan evaluasi tugas yang diberikan dosen. Selain itu, Wa juga menjadi sarana untuk mengukur keaktifan mahasiswa dalam mengikuti pembelajaran.

\section{Simpulan}

Penelitian pembelajaran via whatsapp dalam situasi pendemi COVID 19 memiliki tiga kesimpulan yaitu: 
1. Pembelajaran menggunakan fitur WA sama dengan pembelajaran di kelas tatap muka. Pembelajaran menggunakan fitur WA dilakukan dengan tahapan salam yang dilakukan dengan mengucapkan assalamu'alaikum. Langakh selanjutnya penyampaian tujuan pembelajaran dapat dilakukan dengan pesan singkat/pesan suara. Langkah ketiga penyampaian motivasi awal untuk meningkatkan semangat belajar mahasiswa. Tidak lupa dosen melakukan pembukaan dengan presensi menggunakan pesan singkat yang diisi mahasiswa satu persatu hingga keseluruhan mahasiswa telah mengisi pesan singkat berupa presensi. Penerapan metode pembelajaran juga diawali dengan penjelasan dosen menggunakan pesan singkat atau pesan suara. Setelah pembelajaran selesai diakhiri dengan penutup, berdoa dan pemberian tugas atau materi selanjutnya.

2. Fitur WA yang bisa digunakan dalam pembelajaran daring ini dapat berupa pesan singkat, video, gambar, dokumen file, dan pesan suara. Proses penggunaan fitur WA berupa pesan singkat digunakan dengan mengirimkan pesan singkat tugas dan materi pembelajaran yang disampaikan awal, fitur video digunakan dengan mengirimkan video pembelajaran ke dalam grup WA, fitur gambar digunakan dengan mengirim gambar baik berupa tugas-tugas atau materi berupa gambar, fitur dokumen file digunakan mengirim ppt, word, dan materi pdf yang diperlukan oleh mahasiswa, dan terakhir fitur pesan suara digunakan untuk menjelaskan presentasi mahasiswa dan penjelasan materi atau pertanyaan mahasiswa yang mengalami kesulitan dalam pemahaman materi yang disampaikan dosen.

3. Evaluasi adalah suatu rencana penilaian yang akan dilakukan oleh pendidik. Evaluasi dalam penelitian ini adalah seluruh komponen dari input, proses, hingga hasil belajar pembelajaran yang bisa dilakukan menggunakan media WA, yaitu tanya jawab, mengerjakan pretest/ postest dengan waktu yang ditentukan kemudian mengirimkan hasil pengerjaan soal melalui WA pribadi, presentasi dan diskusi; pembuatan makalah; pengiriman tugas pembuatan analisis buku elektronik.

Saran untuk penelitian selanjutnya yaitu untuk melaksanakan penelitian lebih spesifik menggunakan metode kuantitatif untuk mengukur hasil belajar mahasiswa, kemandirian mahasiswa, dan kreatifitas yang diperoleh mahasiswa setelah melaksanakan pembelajaran online menggunakan media whatsapp.

\section{Daftar Rujukan}

Achmad. (2000). Teori Pembelajaran. Bandung: PT Remaja Rosdakarya.

Arifin, Z. (2013). Evaluasi Pembelajaran. Bandung: PT Remaja Rosdakarya.

Basrudin, Ratman, \& Gagaramusu, Y. (2014). Penerapan Metode Tanya Jawab untuk Meningkatkan Hasil Belajar. Journal Kreatif Tadulako, 1, 214-227.

Chaeruman, U. A. (2017). Panduan Merancang Mata Kuliah Daring SPADA Indonesia. Ristekdikti. 
Citra, S. (2018). No Title.

Daryanto. (2010). Media Pembelajaran. Yogyakarta: Gava Media.

Dimyanti, \& Mudjiono. (2009). Belajar dan Pembelajaran. Jakarta: PT Rineka CIpta.

Effendy, I. (2016). Pengaruh Pemberian Pre-Test dan Post-Test Terhadap Hasil Belajar Mata Diklat HDW.DEV.100.2.a pada Siswa SMK Negeri 2 Lubuk Basung. Jurnal Ilmiah Pendidikan, 1(2), 81-88.

Ermi, N. (2015). Penggunaan Metode Diskusi untuk Meningkatkan Hasil Belajar Materi Perubahan Sosial pada Siswa Kelas XII SMA Negeri 4 Pekanbaru. Sorot, 10(2), 155. https://doi.org/10.31258/sorot.10.2.3212

Jumiatmoko, M. (2016). Whatsapp Messenger Dalam Tinjauan Manfaat Dan Adab. Wahana Akademika: Jurnal Studi Islam Dan Sosial, 3(1), 51. https://doi.org/10.21580/wa.v3i1.872

Kemenristekdikti, T. (2017). BUKU PANDUAN Pengisian Survei Pembelajaran dalam Jaringan. 1-23.

LIPI. (2015). Modul Teknik Presentasi. In Pusbindiklat Peneliti (Vol. 53). https://doi.org/10.1017/CBO9781107415324.004

Naidu. (2006). e-LEarning: A Guidebook of Principles, Procedures, and Practices. New Delhi: Aishi Creative.

Pangestika, N. L. (2018). Pengaruh Pemanfaatan Media Sosial Whatsapp Terhadap Penyebaran Informasi Pembelajaran di SMA Negeri 5 Depok.

Priatmoko, S., \& Dzakiyyah, N. I. (2020). Relevansi Kampus Merdeka Terhadap Kompetensi Guru Era 4.0 Dalam Perspektif Experiential Learning Theory. AtThullab: Jurnal Pendidikan Guru Madrasah Ibtidaiyah, 4(1), 1. https://doi.org/10.30736/atl.v4i1.120

Rahartri. (2019). "Whatsapp" Media Komunikasi Efektif Masa Kini (Studi Kasus Pada Layanan Jasa Informasi Ilmiah Di Kawasan Puspiptek). Visi Pustaka, 21(2), 147156. https://doi.org/10.37014/visi\%20pustaka.v21i2.552

Sofyana, L., \& Rozaq, A. (2019). Pembelajaran Daring Kombinasi Berbasis Whatsapp Pada Kelas Karyawan Prodi Teknik Informatika Universitas Pgri Madiun. Jurnal Nasional Pendidikan Teknik Informatika (JANAPATI), 8(1), 81. https://doi.org/10.23887/janapati.v8i1.17204

Sugiyono. (2014). Metode Penelitian Kuantitatif, Kualitatif, dan $r 7$ D. Bandung: Alfabeta.

Suparlan, S. (2019). Teori Konstruktivisme dalam Pembelajaran. Islamika, 1(2), 79-88. https://doi.org/10.36088/islamika.v1i2.208

Suryadi, E., M.H.Ginanjar., M. P. (2018). Penggunaan Sosial Media WhatsApp dan Pengaruhnya Terhadap Disiplin Belajar Peserta Didik Pada Mata Pelajaran Pendidikan Agama Islam. Jurnal Pendidikan Islam, 07(1), 23-46. https://doi.org/10.30868/EI.V7

Susilo, A., Rumende, C. M., Pitoyo, C. W., Santoso, W. D., Yulianti, M., Herikurniawan, H., ... Yunihastuti, E. (2020). Coronavirus Disease 2019: Tinjauan Literatur Terkini. Jurnal Penyakit Dalam Indonesia, 7(1), 45. https://doi.org/10.7454/jpdi.v7i1.415

Trisnani, -. (2017). Pemanfaatan Whatsapp Sebagai Media Komunikasi Dan Kepuasan 
Dalam Penyampaian Pesan Dikalangan Tokoh Masyarakat. Jurnal Komunika: Jurnal Komunikasi, Media Dan Informatika, 6(3). https://doi.org/10.31504/komunika.v6i3.1227

Widoyoko, E. P. (2014). Hasil Pembelajaran di Sekolah. Yogyakarta: Pustaka Pelajar.

Yudhanto, Y., Yang, Y., Cornelius, L. F., Sulistyanto, M. P. T., Nugraha, D. A., Sari, N., ... Qomarudin, M. N. (2015). Esensi Pengembangan Pembalajaran Daring. Proceedings of the 2017 IEEE International Conference on Applied System Innovation: Applied System Innovation for Modern Technology, ICASI 2017, 1(3), 131. https://doi.org/10.1109/ICASI.2017.7988469 